\title{
Cytotoxicity Assessment of Siparuna cymosa Essential Oil in the Presence of Myeloid Leukemia Cells
}

\author{
da Silva, R. O.; Evangelista, F. C. G.; Sabino, A. P.; da Silva, L. A. M.; de Oliveira, F. F.; \\ de Oliveira, R. A.*
}

Rev. Virtual Quim., 2020, 12 (6), 1381-1388. Data de publicação na Web: 17 de Setembro de 2020

http://rvq.sbq.org.br

\section{Avaliação Citotóxica do Óleo Essencial de Siparuna cymosa Frente a Células de Leucemia Mielóide}

Resumo: Nesse trabalho é apresentado a caracterização química do óleo essencial de Siparuna cymosa (Siparunaceae), espécie endêmica da Mata Atlântica, bem como sua avaliação citotóxica frente a linhagem de células tumorais. O óleo foi extraído das folhas secas por hidrodestilação, caracterizado (CG-EM) e submetido a teste de citotóxica através do método colorimétrico usando brometo de 3-(4,5-dimetil-2-tiazolil)-2,5-difenil-tetrazólio (MTT) em linhagens de LMA, Leucemia Mielóide Aguda, (THP-1) e LMC, Leucemia Mielóide Crônica (K562). O teor médio de óleo foi de 2,11\%, tendo como composto majoritário $\alpha$-bisabolol $(68,9 \%)$ e, em quantidade significativas, $p$-cimen-9-ol $(7,9 \%)$ e espatulenol (3,7\%). Os valores de $\mathrm{Cl}_{50}$ foram de $25,44 \pm 1,55 \mu \mathrm{g} \mathrm{mL}^{-1}$ (LMC) e 30,88 $\pm 2,45 \mu \mathrm{g} \mathrm{mL}$ (LMA). $^{-1}$ (LMA O óleo essencial apresenta moderada ação citotóxica frente as células leucêmicas, destacando-se a LMA que obteve maior índice de seletividade

Keywords: Siparunaceae; análise CG-EM; bisabolol; THP-1; K562.

\begin{abstract}
This work presents the chemical characterization of the essential oil obtained from the Siparuna cymosa (Siparunaceae), an endemic species of the Atlantic Rainforest, as well as its cytotoxicity assessment in the presence of tumor cells. The oil was extracted from dry leaves by hydrodistillation and characterized (GC-FID, GC-MS); and its cytotoxicity was assessed by 3-(4,5-dimethyl-2-thyazolyl)-2,5-diphenyl-tetrazolium bromide (MTT) colorimetric method in AML, Acute Myeloid Leukemia (THP-1) and CML, Chronic Myeloid Leukemia (K652) cell lines. The average oil content was $2.11 \%$ with the major compound being $\alpha$-bisabolol (68.9\%) and, in significant amounts, $p$-cymen-9-ol (7.9\%) and spathulenol (3.7\%). The IC ${ }_{50}$ obtained were the $25.44 \pm 1.55 \mu \mathrm{g} \mathrm{mL}^{-1}(\mathrm{CML})$, and $30.88 \pm 2.45 \mathrm{\mu g} \mathrm{mL}^{-1}(\mathrm{AML})$. The essential oil exhibits moderate cytotoxic action in the presence of leukemia cells, especially $A M L$, for which the selectivity index was higher.
\end{abstract}

Palavras-chave: Siparunaceae; GC-MS analysis; bisabolol; THP-1; K562.

\footnotetext{
* Universidade Estadual de Santa Cruz, Departamento de Ciências Exatas e Tecnológicas, Rodovia Jorge Amado, Km-16, Salobrinho, CEP 45662-900, Ilhéus-BA, Brasil.

Mrosilene@uesc.br DOI: $\underline{10.21577 / 1984-6835.20200109}$
} 


\section{Cytotoxicity Assessment of Siparuna cymosa Essential Oil in the Presence of Myeloid Leukemia Cells}

\section{Rafaela Oliveira da Silva, ${ }^{\mathrm{a}}$ Fernanda Cristina Gontijo Evangelista, ${ }^{\mathrm{b}}$ Adriano de Paula Sabino, ${ }^{b}$ Luiz Alberto Mattos da Silva, ${ }^{c}$ Fernando Faustino de Oliveira, ${ }^{a}$ Rosilene Aparecida de Oliveira ${ }^{\mathrm{a}, *}$}

a Universidade Estadual de Santa Cruz, Departamento de Ciências Exatas e Tecnológicas, Rodovia Jorge Amado, Km-16, Salobrinho, CEP 45662-900, Ilhéus-BA, Brasil.

b Universidade Federal de Minas Gerais, Departamento de Análises Clínicas e Toxicológicas, Faculdade de Farmácia, Av. Antônio Carlos 6627, Pampulha, CEP 31270-901, Belo Horizonte-MG, Brasil

c Universidade Estadual de Santa Cruz, Departamento de Ciências Biológicas, Rodovia Jorge Amado, Km-16, Salobrinho, CEP 45662-900, Ilhéus-BA, Brasil.

*rosilene@uesc.br

Recebido em 26 de Março de 2020. Aceito para publicação em 04 de Agosto de 2020.

\section{Introduction}

\section{Methodology}

2.1. Plant material

2.2. Essential oil extraction and chemical analysis

2.3. Artemia salina lethality assay

2.4. Cytotoxicity assay

\section{Results and Discussions}

\subsection{Essential oil}

3.2. Artemia salina lethality assay

\subsection{Cytotoxicity assay}

\section{Conclusion}

\section{Introduction}

Leukemias are malignant neoplasms in young hematopoietic cells that result in the unregulated proliferation of mutated cells that exhibit changes in differentiation and apoptosis mechanisms. Leukemias are grouped based on the affected cell line, and may be lymphoid or myeloid. They may also be classified as acute or chronic, in accordance with their clinical manifestation. ${ }^{1}$
Chronic myeloid leukemia (CML) is a myeloproliferative disease of the bone marrow, a type of cancer, resulting from the reciprocal translocation between thelongarms ofchromosomes 9 and 22, which give rise to the Philadelphia chromosome (Ph). ${ }^{1}$ Acute myeloid leukemia (AML) is characterized by the clonal expansion of immature cells, resulting in the abnormal build-up of these cells in the bone marrow, leading to a reduction in other cells' production, such as red blood cells, leukocytes and platelets. The build-up of these immature cells, 
in most cases, occurs in the blood and may spread to other body parts, such as lymph nodes, spleen, liver, testicles, and central nervous system. ${ }^{2}$ The onset of resistance to chemotherapy represents a great obstacle to improving the response to treatment and patient survival.

The discovery of some isolated antitumor agents in plant species, such as vincristine, vinblastine, or taxol is a motivation for researching new plant substances with cytotoxic action for tumor cells. Essential oils may exhibit cytotoxic action and some examples can be found from the species of Casearia sylvestris, ${ }^{3}$ Philippine calamansi, ${ }^{4}$ Potentilla descolorir, ${ }^{5}$ Chenopodium ambrosioides, ${ }^{6}$ and Pistacia khinjuk . ${ }^{7}$

The different plant species studied for medicinal purposes include the Siparuna genus. In 2003, despite this genus being recognized by many taxonomists as belonging to the Monimiaceae family, it was segregated to the Siparunaceae family by the APG II, Angiosperm Phylogeny Group. The Siparuna genus, native of South America, consists of approximately 65 species. $^{8}$

Ethnopharmacological studies reveal that some species have been used popularly, being the most frequently studied one the $S$. guianensis species. This species' leaves are used to treat stomach disorders, headaches and rheumatism, chills, fevers, blood pressure, rheumatic diseases, and cramps. ${ }^{8}$ Its extract is used as an insecticide. ${ }^{8}$ It is also used as an anxiolytic drug by South American indigenous peoples and by riparian populations. ${ }^{9}$ Other studies report the use of $S$. apiosyce in treating dyspepsia, flatulence, coughs, bronchitis, and laryngitis, skin diseases, fevers, flus, headaches, rheumatism, ${ }^{10}$ and snakebites. ${ }^{11} \mathrm{~S}$. thecaphora is used to treat colds and headaches..$^{12}$ S. pauciflora leaves are also used by indigenous peoples to treat fevers. ${ }^{13}$

Fonseca et al. (2008) reported on the antibacterial activity of the $S$. sessiliflora leaves' alkaloid fraction in the presence of Bacillus subtilis. S. arianeae leaves' raw extract exhibited antibacterial activity in the presence of Mycobacterium malmoense. ${ }^{14}$

Siparuna species' essential oils are not frequently studied. To contribute to the search for substances with cytotoxic action in the presence of AML (THP-1) and CML (K562), this article shows the extraction and characterization of the $S$. cymosa, as well as it's cytotoxicity assessment in the present of these cells. S. cymosa is an endemic species from southern Bahia, Brazil, an Atlantic rainforest region. Our research group was the first to study this species

\section{Methodology}

\subsection{Plant material}

S. cymosa Tolm. species leaves were collected in May 2017, in the city of UNA (GPS $15^{\circ}$ $12^{\prime} 34.2^{\prime \prime} \mathrm{S}$ and $39^{\circ} 03^{\prime} 36.4^{\prime \prime} \mathrm{W}$ ), Bahia, Brazil. The taxonomical identification of the species was done by botanist Luiz Alberto Mattos and the specimen voucher was deposited in the Herbarium of the State University of Santa Cruz, registered under number 16332. The leaves were dried in a forcedventilation greenhouse at $40^{\circ} \mathrm{C}$ for 2 days.

\subsection{Essential oil extraction and chemical analysis}

The essential oil was extracted from $30 \mathrm{~g}$ of dry leaves that were cured in 1.5 liters of distilled water, using a Clevenger apparatus, for 90 minutes. The essential oil was separated from the hydrolate using the extraction with dichloromethane, subsequently dried with anhydrous sodium sulfate, and concentrated. The content was expressed in percentages, based on the ratio between the obtained oil mass and the used dry plant material $(\mathrm{w} / \mathrm{w})$, in triplicates. The oil was stored at $-10^{\circ} \mathrm{C}$.

The quantitative analysis of volatile oil was obtained by means of gas chromatography with flame ionization detector (GC-FID) using the gas chromatography system (Varian, Chrompack, CP3800 ), equipped with fused silica capillary column VF5-ms ( $30 \mathrm{~m} \times 0.25 \mathrm{~mm}$ ) with $5 \%$ phenyl and $95 \%$ dimethylpolysiloxane stationary phase $(0.25 \mu \mathrm{m}$ film thickness), using 5.0 helium as the carrier gas, with a flow at $1.2 \mathrm{ml} \mathrm{min}^{-1}$ (12 psi). Injector and detector temperatures were 250 and $280^{\circ} \mathrm{C}$, respectively. A $1.0 \mu$ l solution in $10 \%$ chloroform was injected, in split mode (1:10). The column temperature started at $60^{\circ} \mathrm{C}$, with an $8^{\circ} \mathrm{C}$ per minute increase until it reached the temperature of $260^{\circ} \mathrm{C}$, at which it was maintained for 5 minutes. The analysis time was 30 minutes. Component quantification present in the oil was obtained by electronic integration of the peaks detected in the FID by normalization, in triplicates. 
Qualitative analysis of the essential oil was done by GC-MS, using the Varian (Chromopack Saturn 2000/2000) chromatography system equipped with the same capillary column and under the same conditions adopted for the GCFID analysis. Helium 6.0 was used as the carrier gas, with a flow at $1.0 \mathrm{ml} \mathrm{min}^{-1}(10 \mathrm{psi})$. An ion trap analyzer was used, with transferline, manifold, and trap temperatures at $280^{\circ} \mathrm{C}, 50^{\circ} \mathrm{C}$, and $150^{\circ} \mathrm{C}$, respectively. The mass range analyzed was from 60 to 450 dalton. To identify the substances, present in the essential oil, the fragmentation patterns observed in the mass spectra were compared to the present study results in a NIST 11.0 database, and retention rates obtained with the injection of a $\mathrm{C}_{8}-\mathrm{C}_{26}$ (Sigma-Aldrich-USA) hydrocarbon mix, under the same analytical conditions, were compared to data from the literature. ${ }^{15}$

\subsection{Artemia salina lethality assay}

Artemia salina nauplius larvae were placed in a saline solution, under artificial lighting for $48 \mathrm{~h}$, for eclosion. After this time, 10 microcrustaceans were counted and placed in transparent containers with a $5 \mathrm{~mL}$ resulting solution consisting of sea water, $1 \mathrm{~mL}$ Tween 80 at 5\%, and five different concentrations of essential oil (1000 - 500 - 300

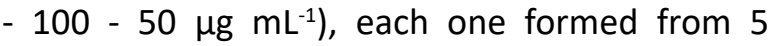
replicates. Sea water and a $5 \%$ Tween 80 solution were used as control in triplicates. A new count was performed 24 hours after the microcrustaceans were added in the present of light in order to determine the number of live and dead microcrustaceans at each concentration level. The interpolation method, in which the percentage of live and dead microcrustaceans is correlated, based on concentration, was used as the evaluation parameter to determine $\mathrm{LC}_{50}$.

\subsection{Cytotoxicity assay}

The cytotoxic activity assessment used the 3-(4,5-dimethyl-2-thyazolyl)-2,5-diphenyltetrazolium bromide colorimetric assay (MTT, Sigma-Aldrich) with an Acute Myeloid Leukemia cell line (ATCC TIB-202, THP-1) and a Chronic Myeloid Leukemia cell line (ATCC CRL-3344, K562). The cells were placed on 96-well plates ( $2 \times 10^{5}$ cells per well) and incubated for 24 hours at $37^{\circ} \mathrm{C}$ in a humid atmosphere, with $5 \% \mathrm{CO}_{2}$. After $24 \mathrm{~h}$, the wells were washed with culture medium (RPMI1640 + heat-inactivated fetal bovine serum at $20 \%+$ $2 \mathrm{~m} \mathrm{~mol} \mathrm{~L}^{-1} \mathrm{~L}$-glutamine) and incubated with samples at 0.10 to $100 \mu \mathrm{g} \mathrm{mL}^{-1}$ concentrations. After a 48 -hour incubation period, the plates were treated with MTT $\left(5 \mathrm{mg} \mathrm{mL}^{-1}\right.$ ). Colorimetric measurements were done at $550 \mathrm{~nm}$, using the Spectramax M5e microplate reader. The cytarabine and imatinin mesylate were used as controls for THP-1 and K562, respectively. All experiments were performed in triplicates. The results were expressed by the $I_{50}$ values (drug concentration that reduced the cell viability at $50 \%)$. The $\mathrm{IC}_{50}$ were calculated using the software OriginPro 8.0.

The selectivity index (SI) corresponds to the essential oil IC $C_{50}$ value in the presence of normal cell lines divided by the essential oil IC $C_{50}$ value in the presence of neoplastic cell lines $-\mathrm{Sl}=$ normal cell $\mathrm{IC}_{50} /$ neoplastic cell $\mathrm{IC}_{50}{ }^{16}$

\section{Results and Discussions}

\subsection{Essential oil}

The average essential oil content was $2.11 \pm$ $0.09 \%$; therefore, if compared to the oil contents for other Siparuna species, the $S$. cymosa exhibits high oil content. The $S$. guianesis exhibited essential oil content of $0.13-0.24 \%$, for leaves, and of $0.04-0.09 \%$, for branches. ${ }^{17}$ S. thecaphora dry leaves exhibited an oil content of $0.12 \%,{ }^{18}$ while the $S$. eggersii fresh leaves exhibited a content of $0.19 \% .{ }^{19}$

The essential oil chromatography analysis allowed to identify 20 components, representing $97.0 \%$ of total volatiles that could be divided into monoterpenes (10.7\%), phenylpropanoids (1.3\%), sesquiterpenes (3.7\%), and oxygenated sesquiterpenes (81.3\%), Figure 1 and Table 1. The $\alpha$-bisabolol (68.3\%) is the primary major component in the oil; while p-cymen-9-ol (7.9\%) and spathulenol (3.7\%) have also been identified in significant amounts.

The $\alpha$-bisabolol has a $222 \mathrm{~g} \mathrm{~mol}^{-1}$ molecular mass, with base peak at $\mathrm{m} / \mathrm{z} 109 \mathrm{~g} \mathrm{~mol}^{-1}$. This compound was also identified in the $S$. guianensis essential oil. ${ }^{20}$ The compound spathulenol has a molecular mass of $220 \mathrm{~g} \mathrm{~mol}^{-1}$ with a base peak at $\mathrm{m} / \mathrm{z} 119 \mathrm{~g} \mathrm{~mol}^{-1}$. Its presence was also reported in essential oils extracted from $S$. thecaphora 


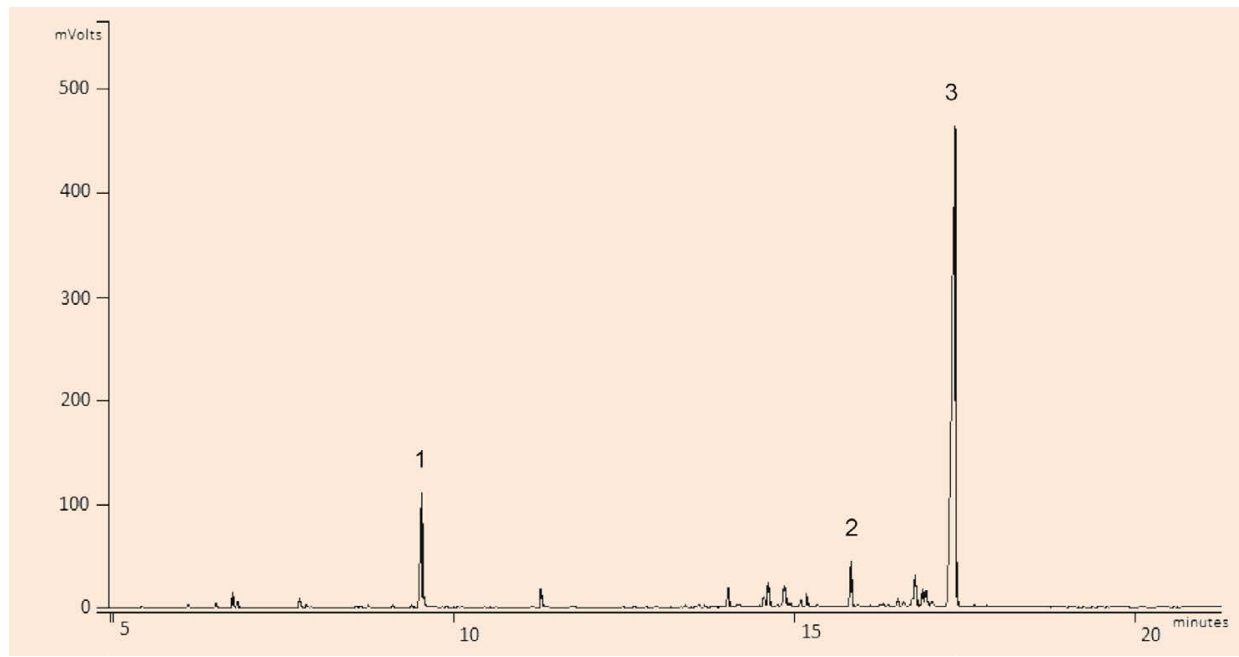

Figure 1. Chromatogram (GC-FID) of the essential oil extracted from Siparuna cymosa leaves, highlighting the major substances: 1: p-Cymen-9-ol; 2: Spathulenol; 3: $\alpha$-Bisabolol

Table 1. Chemical composition of the Siparuna cymosa essential oil

\begin{tabular}{|c|c|c|c|}
\hline Substances & RI (Exp) & RI (Lit) & Relative area (\%) \\
\hline 3- $\delta$-Carene & 1010 & 1011 & $0.5 \pm 0.0$ \\
\hline o-Cymene & 1027 & 1027 & $1.1 \pm 0.2$ \\
\hline$p$-Cymene & 1031 & 1026 & $0.6 \pm 0.1$ \\
\hline p-Menta-2,4 (8)-diene & 1085 & 1086 & $0.6 \pm 0.1$ \\
\hline$p$-Cymen-9-ol & 1195 & 1206 & $7.9 \pm 0.6$ \\
\hline Safrole & 1292 & 1285 & $1.3 \pm 0.2$ \\
\hline epi-Cubenol & 1496 & 1493 & $0.8 \pm 0.1$ \\
\hline$\beta$-Bisabolene & 1503 & 1509 & $1.7 \pm 0.1$ \\
\hline Cubebol & 1517 & 1514 & $2.0 \pm 0.2$ \\
\hline$\delta$-Cadinene & 1522 & 1524 & $0.6 \pm 0.0$ \\
\hline$\gamma$-(E)-Bisabolene & 1536 & 1531 & $0.5 \pm 0.0$ \\
\hline Germacrene-B & 1542 & 1556 & $0.9 \pm 0.1$ \\
\hline Spathulenol & 1581 & 1576 & $3.7 \pm 0.3$ \\
\hline 1-epi-Cubenol & 1630 & 1628 & $0.7 \pm 0.0$ \\
\hline Muurola-4,10(14)-dien-1-- $\beta$-ol & 1636 & 1631 & $0.6 \pm 0.0$ \\
\hline Cubenol & 1645 & 1642 & $0.8 \pm 0.0$ \\
\hline$\alpha$-Cadinol & 1650 & 1653 & $2.3 \pm 0.0$ \\
\hline$\alpha$-Bisabolol oxide-B & 1657 & 1655 & $1.4 \pm 0.0$ \\
\hline$\beta$-Bisabolol & 1670 & 1671 & $0.7 \pm 0.0$ \\
\hline$\alpha$-Bisabolol* & 1699 & 1686 & $68.3 \pm 1.8$ \\
\hline Monoterpenes & \multicolumn{3}{|c|}{10.7} \\
\hline Phenylpropanoids & \multicolumn{3}{|c|}{1.3} \\
\hline Sesquiterpenes & \multicolumn{3}{|c|}{3.7} \\
\hline Oxygenated sesquiterpenes & \multicolumn{3}{|c|}{81.3} \\
\hline Total identified (\%) & \multicolumn{3}{|c|}{97.0} \\
\hline
\end{tabular}

$\mathrm{RI}$ (Exp): Retention Index calculated based on the pattern injections $\mathrm{C}_{8}-\mathrm{C}_{26}$; RI (Lit.) Literature Retention Index; ${ }^{15}$ Relative percentage based on the normalization of the chromatographic peaks; $n=3 ;{ }^{*}$ confirmed with authentic standard 
leaves, ${ }^{12}$ S. eggerssi leaves, ${ }^{19}$ and S. guianensis leaves, ${ }^{21}$ as well as from the $S$. thecaphora fruit. ${ }^{12}$ The compound $p$-cymen-9-ol has a molecular mass of $150 \mathrm{~g} \mathrm{~mol}^{-1}$ with a base peak at $\mathrm{m} / \mathrm{z} 134.9 \mathrm{~g}$ $\mathrm{mol}^{-1}$. This is the first time this compound has been reported in essential oils from species of this genus.

\subsection{Artemia salina lethality assay}

The essential oil exhibited $\mathrm{LC}_{50}$ of $29.00 \mathrm{\mu g} \mathrm{mL}^{-1}$, which is considered to be lethal in the presence of $A$. salina. ${ }^{22}$ Studies have shown the correlation between the lethality test in the presence of $A$. salina and the in vitro growth inhibition of tumor cells; recognizing this experiment, with simple and easy execution, as a preliminary evaluation form for the cytotoxicity assessment of substances in the presence of antitumor cells. ${ }^{22}$

\subsection{Cytotoxicity assay}

Figure 2 shows the results of cytotoxicity assays for MTT tests in THP-1 and K562 cell lines. The control substances (chemotherapeutics) used in this study were cytarabine (THP-1) and imatinib mesylate (K562). The $\mathrm{IC}_{50}$ values obtained for the essential oil in $\mathrm{K} 562\left(30.88 \pm 2.45 \mu \mathrm{g} \mathrm{mL}^{-1}\right)$ and THP$1\left(25.44 \pm 1.55 \mu \mathrm{g} \mathrm{mL}^{-1}\right)$ were very similar and lower than $30.0 \mu \mathrm{g} \mathrm{mL}^{-1}$, indicating cytotoxic activities. ${ }^{23,24}$

The essential oil exhibited a PBMC (Peripheral Blood Mononuclear Cells) cytotoxic value of $80.20 \pm 4.11 \mu \mathrm{g} \mathrm{mL} \mathrm{m}^{-1}$, which is not considered cytotoxic in the presence of these normal cells. The PBMC values for cytarabine and imatinib mesylate were of $58.70 \pm 3.76$ and $69.63 \pm 3.13 \mu \mathrm{g}$ $\mathrm{mL}^{-1}$, respectively. The SI on the THP-1 cell line was 3.15 for the essential oil while the cytarabine index was 4.62. On K562 cells, the SI was 2.60 for the essential oil, whereas the imatinib index was 6.63. Based on these results, despite chemotherapeutics shows a better index than the essential oil analyzed here, the essential oil exhibits actions on both types of tumor cells.

The $\alpha$-bisabolol, primary component of the essential oil exhibits such activities as antimutagenic, anti-inflammatory, antifungal, antibacterial, and gastroprotective action. ${ }^{25,26}$

This compound also exhibited cytotoxic activity, in glioma tumor cell lines in mice, and it was quite selective. ${ }^{27}$ In addition, it has cytotoxic activity in the presence of other tumor cell lines, such as melanoma, breast adenocarcinoma, liver carcinoma, lung carcinoma, pancreatic cancer, acute leukemia, and acute myeloid leukemias, resulting, in all of these cases, in death by apoptosis. ${ }^{28}$

Studies conducted by Alcântara et al (2010) show spathulenol action, also present in the essential oil, as a bactericide, in addition to exhibiting moderate cytotoxic activity in the presence of KB type cells (oral carcinoma). ${ }^{29}$

In addition to providing great yields, the $S$. cymosa oil, based on our biological assessment studies, may exhibit other activities, leading us to proceed with studies about the species.

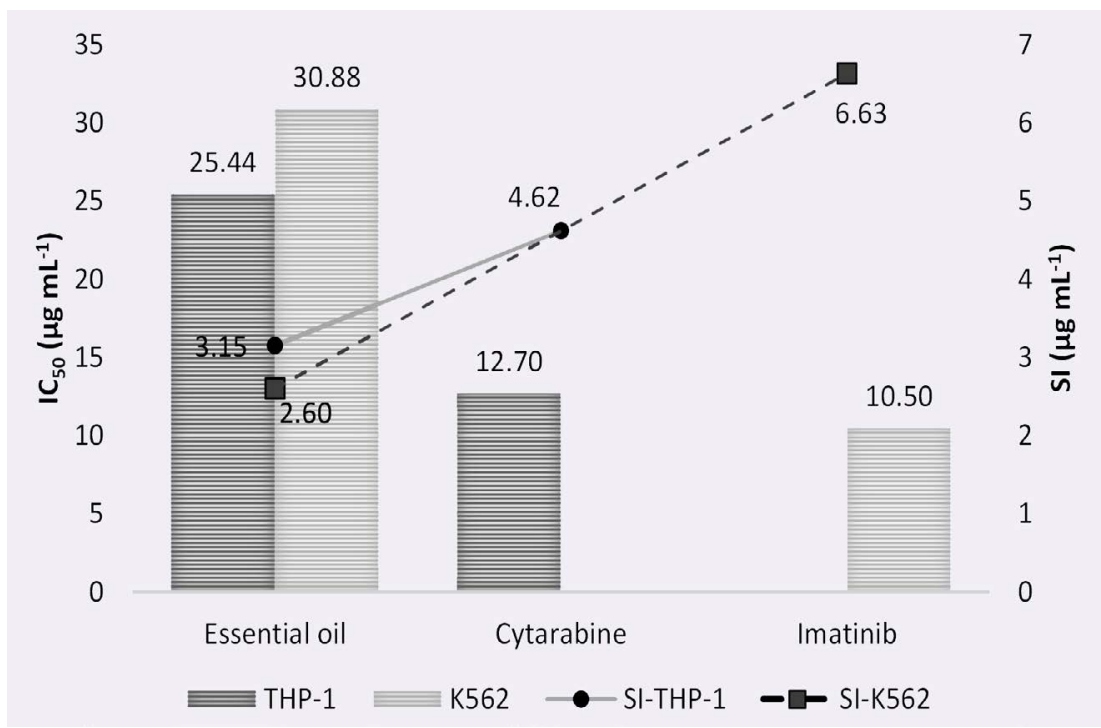

Figure 2. Cytotoxicity assay data for the species Siparuna cymosa essential oil. THP-1 and K562: Cell lines; SI: selectivity Index., Cytarabine and Imatinib mesylate: control substance for THP-1 and K562, respectively 


\section{Conclusion}

The species studied herein is promising as a source of essential oil rich in $\alpha$-bisabolol, being of great interest in the pharmaceutical and cosmetic areas. The essential oil presented high lethality against $A$. salina. In addition, the results indicated cytotoxic activity against the AML and CML tumour cell lines, with selectivy index higher for AML cells. Thus, the study of the S. cymosa species of the south region of Bahia becomes promising, since this work presented interesting results, and not yet recorded in the literature.

\section{Acknowledgments}

The authors wish to thank the support from the Coordenação de Aperfeiçoamento de Pessoal de Nível Superior (CAPES - Coordination for the Improvement of Higher Education Personnel) for the grant received, from the Graduate Program in Chemistry (PPGQUIM), and the Departamento de Análises Clínicas e Toxicologicas, UFMG.

\section{References}

${ }^{1}$ Heiblig, M.; Sobh, M.; Nicolini, F. E. Subcutaneous omacetaxine mepesuccinate in patients with chronic myeloid leukemia in tyrosine kinase inhibitor-resistant patients: Review and perspectives. Leukemia Research 2014, 38, 1145. [CrossRef] [PubMed]

${ }^{2}$ Bittencourt, R.; Fogliato, L.; Daudt, L.; Bittencourt, H.N.; Friederich, J.R.; Fernandes, V, Onsten, T.; Fassina, K.; Rocha, L. K .; Moreno, F.; Silva, G.; Cruz, M.S.; de Garcia, R.G.; Masniersky, J. C.; Silla, L. M. Leucemia Mielóide Aguda: perfil de duas décadas do Serviço de Hematologia do Hospital de Clínicas de Porto Alegre-RS. Revista Brasileira de Hematologia e Hemoterapia 2003, 25, 15. [Link] ${ }^{3}$ Da Silva, S. L.; Chaar, J. D. S.; Figueiredo, P. D. M. S.; Yano, T. Cytotoxic evaluation of essential oil from Casearia sylvestris Sw on human cancer cells and erythrocytes. Acta Amazonica 2008, 38, 107. [CrossRef]

${ }^{4}$ Palma, C. E.; Cruz, P. S.; Cruz, D. T. C.; Bugayong, A. M. S.; Castillo, A. L. Chemical composition and cytotoxicity of Philippine calamansi essential oil. Industrial Crops and Products2019, 128, 108. [CrossRef]
${ }^{5}$ Zhang, J.; Huang, R. Z.; Cao, H. J.; Cheng, A. W.; Jiang, C. S.; Liao, Z. X.; Liu, C.; Sun, J. Y. Chemical composition, in vitro anti-tumor activities and related mechanisms of the essential oil from the roots of Potentilla discolor. Industrial Crops and Products 2018, 113, 19. [CrossRef]

${ }^{6}$ Degenhardt, R. T.; Farias, I. V.; Grassi, L. T.; Franchi, G. C.; Nowill, A. E.; Bittencourt, C. M. d. S.; Wagner, T. M.; de Souza, M. M.; Cruz, A. B.; Malheiros, A. Characterization and evaluation of the cytotoxic potential of the essential oil of Chenopodium ambrosioides. Revista Brasileira de Farmacognosia 2016, 26, 56. [CrossRef]

7 Taghizadeh, S. F.; Davarynejad, G.; Asili, J.; Riahi-Zanjani, B.; Nemati, S. H.; Karimi, G. Chemical composition, antibacterial, antioxidant and cytotoxic evaluation of the essential oil from pistachio (Pistacia khinjuk) hull. Microbial Pathogenesis 2018, 124, 76. [CrossRef] [PubMed] ${ }^{8}$ Valentini, C. M. A.; Rodríguez-Ortíz, C. E.; Coelho, M. F. B. Siparuna guianensis Aublet (negramina): Uma revisão. Revista Brasileira de Plantas Medicinais 2010, 12, 96. [CrossRef]

9 Rodrigues, E. Plants and animals utilized as medicines in the Jaú National Park (JNP), Brazilian Amazon. Phytotherapy Research 2006, 20, 378. [CrossRef] [PubMed]

${ }^{10}$ Leitão, G. G.; Simas, N. K.; Soares, S. S. V.; de Brito A. P. P.; Claros, B. M. G.; Brito, T. B. M.; Monache, F. D. Chemistry and pharmacology of Monimiaceae: a special focus on Siparuna and Mollinedia. Journal of Ethnopharmacology 1998, 65, 87. [CrossRef] [PubMed] ${ }^{11}$ López, J.; Laurito, J.; Lin, F.-T.; Sharaf, M.; Wong, L.; Schiff, P. Alkaloids of Siparuna Griseoflavescens. Planta Medica 1993, 59, 100. [CrossRef] [PubMed] 12 Cicció, J. F.; Gómez-Laurito, J. Volatile constituents of the fruits of Siparuna thecaphora (siparunaceae) from Costa Rica. Journal of Essential Oil Research 2010, 22, 328. [CrossRef]. ${ }^{13}$ Jenett-Siems, K.; Kraft, C.; Siems, K.; Jakupovic, J.; Solis, P. N.; Gupta, M. P.; Bienzle, U. Sipaucins A - C, sesquiterpenoids from Siparuna pauciflora. Phytochemistry 2003, 63, 377. [CrossRef] [PubMed] 14 Fonseca, T. L.; Groll, A. V.; Leitão, G. G.; Scaini, C. J.; Ramos, D. F.; Silva, P. E. A. Atividade antimicobacteria de extratos vegetais frente a Mycobacterium fortuitum e Mycobacterium malmoense. Vittalle 2008, 20, 65. [Link]

15 Adams, R. P.; Identification of Essential Oil Components by Gas chromatography/ mass Spectrometry, 4 ed. Allured Publishing Corporation: Carol Stream, 2007 
${ }^{16}$ Nakamura, C.V.;Santos,A.O.; Vendrametto, M.C.; Luize, P. S.; Dias Filho, B. P.; Cortez, D. A. G.; Ueda-Nakamura, T. Atividade antileishmania do extrato hidroalcoólico e de frações obtidas de folhas de Piper regnellii (Miq.) C. DC. var. pallescens (C. DC.) Yunck. Revista Brasileira de Farmacognosia 2006, 16, 61. [CrossRef].

17 Castellani, D. C.; Casali, V. W. D.; Souza, A. L.; Cecon, P. R.; Cardoso, C. A.; Marques, V. B. Produção de óleo essencial em catuaba (Trichilia catigua A. Juss) e negramina (Siparuna guianensis Aubl.) em função da época de colheita. Revista Brasileira de Plantas Medicinais 2006, 8, 62. [Link] ${ }^{18}$ Vila, R.; Iglesias, J.; Cañigueral, S.; Santana, A. I.; Solís P. N.; Gupta, M. Chemical composition and biological activity of the leaf oil of Siparuna thecaphora (Poepp. et Endl.) A. DC. Journal of Essential Oil Research 2002, 14, 66. [CrossRef]

19 Ruiz, S.; Malagón, O.; Zaragoza, T.; Valarezo,

E. Composition of the essential oils of Artemisia sodiroi hieron., Siparuna eggersii hieron., Tagetes filifolia lag. and Clinopodium nubigenum (kunth) kuntze from loja ecuador. Journal of Essential Oil Bearing Plants 2010, 13, 676. [CrossRef]

${ }^{20}$ Zoghbi, M. D. G. B.; Andrade, E. H. A.; Santos, A. S.; Silva, M. H. L.; Maia, J. G. S. Essential oils of Siparuna guianensis Aubl. Journal of Essential Oil Research 1998, 10, 543. [CrossRef]

${ }^{21}$ Fischer, D. C.; Limberger, R. P.; Henriques, A. T.; Moreno, P. Essential oils from fruits and leaves of Siparuna guianensis (Aubl.) Tulasne from southeastern Brazil. Journal of Essential Oil Research 2005, 17, 101. [CrossRef]

${ }^{22}$ Mclaughlin, J. L.; Rogers, L. L.; Anderson, J. E. The use of biological assays to evaluate botanicals. Therapeutic Innovation \& Regulatory Science 1998, 32, 513. [CrossRef]

${ }^{23}$ Braga, T. V.; Dores, R. G. R. das; Ramos, C. S.; Evangelista, F. C. G.; Tinoco, L. M. da S.; Varotti, F. de P.; Carvalho, M. das G.; Sabino, A. de P. Antioxidant, Antibacterial and Antitumor Activity of Ethanolic Extract of the Psidium guajava Leaves. American Journal of Plant Sciences 2014, 05, 3492. [CrossRef]
${ }^{24}$ Tiwary, B. K.; Bihani, S.; Kumar, A.; Chakraborty, R.; Ghosh, R. The in vitro cytotoxic activity of ethno-pharmacological important plants of Darjeeling district of West Bengal against different human cancer cell lines. BMC Complementary Medicine and Therapies 2015, 15, 1. [CrossRef] [PubMed]

25 Gomes-Carneiro, M. R.; Dias, D. M. M.; DeOliveira, A. C. A. X.; Paumgartten, F. J. R. Evaluation of mutagenic and antimutagenic activities of $\alpha$-bisabolol in the Salmonella/microsome assay. Mutation Research - Genetic Toxicology and Environmental Mutagenesis 2005, 585, 105. [CrossRef] [PubMed]

${ }^{26}$ Rocha, N. F. M.; Oliveira, G. V. De; Araújo, F. Y. R. De; Rios, E. R. V.; Carvalho, A. M. R.; Vasconcelos, L. F.; Macêdo, D. S.; Soares, P. M. G.; Sousa, D. P. De; Sousa, F. C. F. De. (-)- $\alpha$-Bisabolol-induced gastroprotection is associated with reduction in lipid peroxidation, superoxide dismutase activity and neutrophil migration. European Journal of Pharmaceutical Sciences 2011, 44, 455. [CrossRef] [PubMed]

${ }^{27}$ Cavalieri, E.; Bergamini, C.; Mariotto, S.; Leoni, S.; Perbellini, L.; Darra, E.; Suzuki, H.; Fato, R.; Lenaz, G. Involvement of mitochondrial permeability transition pore opening in $\alpha$-bisabolol induced apoptosis. The FEBS Journal 2009, 276, 3990. [CrossRef] [PubMed]

${ }^{28}$ Cavalieri, E.; Rigo, A.; Bonifacio, M.; de Prati, A. C.; Guardalben, E.; Bergamini, C.; Fato, R.; Pizzolo, G.; Suzuki, H.; Vinante, F. Pro-apoptotic activity of $\alpha$-bisabolol in preclinical models of primary human acute leukemia cells. Journal of Translational Medicine 2011, 9, 1 [CrossRef] [PubMed]

${ }^{29}$ Alcântara, J. M.; De Lima Yamaguchi, K. K.; Da Veiga, V. F.; Lima, E. S. Composição química de óleos essenciais de espécies de Aniba e Licaria e suas atividades antioxidante e antiagregante plaquetária. Química Nova 2010, 33, 141. [CrossRef]t 